\title{
Meningkatkan Kreativitas Anak Usia Dini Melalui Aktivitas Menggambar Pada Anak Kelompok A Paud Tuan Guru Alim
}

\author{
Nurhamsa Mahmud \\ Universitas Khairun Ternate \\ Jl. Bandara Baabullah Kampus 1 Unkhair, Kelurahan Akehuda Kota Ternate Kode Pos 97728 \\ Email: nurhamsaaca@gmail.com
}

\begin{abstract}
Abstrak: Tujuan penelitian ini yakni untuk mendeskripsikan kreativitas anak melalui aktivitas menggambar di Paud Tuan Guru Alim Kota Ternate, dengan mengembangkan kreativitas anak terhadap pematangan fungsi fisik dan psikis yang siap merespon simulasi yang diberikan oleh lingkungan, agar anak pertumbuhannya berkembang dengan optimal. Jenis penelitian yang digunakan dalam penelitian ini adalah penelitian tindakan kelas (PTK). Subjek dalam penelitian ini adalah anak kelompok A Paud Tuan Guru Alim dengan jumlah 10 anak terdiridari 6 perempuan dan 4 laki-laki. Desain Penelitian yang digunakan mengacuh pada model Kemmis dan M.C Taggart, yang terdiri 4 komponen yakni: perencanaan, pelaksanaan, observasi, dan refleksi. Proses penilaian pada pembelajaran melalui aktivitas menggambar terdapat $37,5 \%$ dikategorikan mulai berkembang (MB), dan 25\% dikategorikan sudah berkembang (SB), dan 18,75\% belum berkembang (BB) Sementara pada siklus II mengalami peningkatan yang signifikan $70 \%$ sedang berkembang dan 93\% dikategorikan tuntas. Maka disimpulkan kreativitas anak melalui aktivitas menggambar pada kelompok A Paud Tuan Guru Alim Kota Ternate dapat meningkat secara optimal.
\end{abstract}

Kata kunci: Kreativitas, Menggambar, Perkembangan

Abstract: The purpose of this study is to describe children's creatifity through drawing activities at Paud Tuan Guru Alim in Ternate City, by developing chidren's creativity towards maturing physical and psychological funtions that are ready to respond for simulation given by the enviroment, so that their children's growth develops optimally. This type of research used in this research is classroom action researh (CAR). The subject in this study were the children of groupA Paud Tuan Guru Alim with a total of 10 children consisting of 6 girls and 4 boys. The research design used refers to the odel of Kammis and M.C Taggart, which consists of 4 components, namely: Planning, implementation, observing and reflecting. The assessment process on learning through drawing activities is 37.5\% categorized as starting to develop, and 25\% categorized as developing, and 18.75\% underdeveloped Semntara in cycle II experienced a significant increase of $70 \%$ moderate developing and $93 \%$ categorized as complete. So it was concluded that children's creativity through drawing activities in group A Paud Tuan Guru Alim Ternate City could increase optimally.

Key words: Creativity, Drawing, Development

\section{A. Pendahuluan}

Pada anak usia dini dianggap sangat penting karena merupakan usia emas yang didalamnya terdapat masa peka yang hanya dating sekali diusia 4-6 tahun, masa peka adalah masa peka yang terjadi pematangan fungsi fisik dan psikis yang siap merespon simulasi yang diberikan oleh lingkungan, pada masa ini adalah masa pengembangan kemampuan fisik, oleh karena itu dibutuhkan simulasi - simulasi yang sesuai agar anak pertumbuhannya berkembang dengan optimal. 
Maka dengan simulasi simulasi tersebut kreativitas merupakan hal yang sangat penting dalam kehidupan sehari - hari khususnya pada anak usia dini Karena bisa lebih produktif, perkembangan kreativitas dapat berpengaruh terhadap kehidupan seseorang, pendidik dan orang tua sering mengganggap kegiatan menggambar tidak penting sehingga kuarang adanya bimbingan anak pada hal menggambar, pada hal kegiatatan dan aktivitas menggambar dapat meningkatkan kreativitas, karea dengan adanya kegiatan tersebut secara tidak langsung anak sudah menuangkan dan mengekpresikan ide, perasaan, imajinasi dan gagasan melalui aktivitas menggambar.

Sejalan dengan uraiyan tersebut, untuk mengoptimalkan berbagai potensi anak pada masa pertumbuhannya maka perlu memperhatikan bagaimana cara untuk meningkatkan kreativitas melalui aktivitas menggambar.

\section{B. Kerangka Teoretik}

\section{Pengertian Kreativitas}

Kreativitas adalah kemampuan seseorang menghasilkan suatu produk atau gagasan apa saja yang pada dasarnya baru, munandar (2005:6) kreativitas atau daya cipta memungkinkan penemuan - penemuan baru dalam bidang ilmu dan teknologi serta dalam semua bidang usaha lainnya, Ulfah (2008) kreativitas merupakan segala pikiran baru, cara, pemahaman/ model baru yang dapat disampaikan kemudian digunakan dalam kehidupan. Kreativitas adalah sesuatu proses adanya sesuatu yang baru apakah itu gagasan, atau benda dalam bentuk rangkaiyan yang baru dihasilkan.

\section{Karakteristik kreativitas pada anak usia dini}

Piers dalam Ali Asrori (2006:52) karakteristik kreativitas
a. Memiliki dorongan yang tinggi.
b. Memiliki keterlibatan yang tinggi
c. Memiliki rasa ingin tahu yang besar
d. Memiliki ketekunan yang tinggi
e. Cenderung tidak puas terhadap kemampuan
f. Percaya diri
g. Memiliki kemandirian yang tinggi
h. Bebas mengambil keputusan
i. Menerima diri sendiri
j. Senang humor
k. Memiliki instuisi yang tinggi
l. Cenderung tertarik pada hal - hal yang komplek
m. Toleran terhadap ambiguitas
n. Bersifat sensitive.

\section{Perkembangan Kreativitas Pada Anak Usia Dini}

Kreativitas merupakan kemampuan untuk menciptakan gagasan baru yang imajinatif dan juga kemampuan beradaptasi gagasan barudengan gagasan yang sudah ada. Susanto (2011:114) selanjutnya menurut Munandar (1995:46) Segi pres atau dorongan, kreativitas dapat diwujudkan jika dukungan oleh lingkungan dan kemauan dalam dirinya yang kuat, terdapat dua factor pendukung kemauan seseorang yaituh 
kemauan dari dalam/motivasi intrinsic dan kemauan yang disebabkan oleh karena dorongan dari luar /motovasi ekstrinsik.

\section{Aktivitas Menggambar Pada Anak Usia Dini}

Pembelajaran di TK aktivitas menggambar yangdunakan antara lain jenis menggambar bebas, menggambar imajinatif, dan mewarnai gambar, kegiatan aktivitas menggambar bagi anak adlah media berekspresi dan berkomunikasi yang dapat menciptakan suasana aktif, asyik, dan menyenangkan anak, depdikbud (2005:47) selanjutnya menurut Hajar Pamadhi (2008:2.8) aktivitas menggambar merupakan kegiatan naluriah atau alami bagi anak, karena hamper setiap hari anak dapatmelakukan hal ini untuk bercerita dengan orang lain. Suwarna (2005:10) aktivitas menggambar adalah suatu kegiatan seni lukis yang merupakan sala satu media komunikasi.

\section{Metode Penelitian}

Jenis penelitian yang digunakan dalam penelitian ini adalah penelitian tindakan kelas (PTK). Penelitian ini dilaksanakan Di PAUD Tuan Guru Alim pada bulan oktober 2021. Subjek dalam penelitian ini adalah anak kelompok A Paud Tuan Guru Alim dengan jumlah 10 anak terdiridari 6 perempuan dan 4 laki - laki.

Desain Penelitian yang digunakan mengacuh pada model Kemmis dan M.C Taggart yang terdiri 4 komponen yakni, perencanaan, pelaksanaan, observasi, refleksi. Dengan deskripsi sebagai berikut :

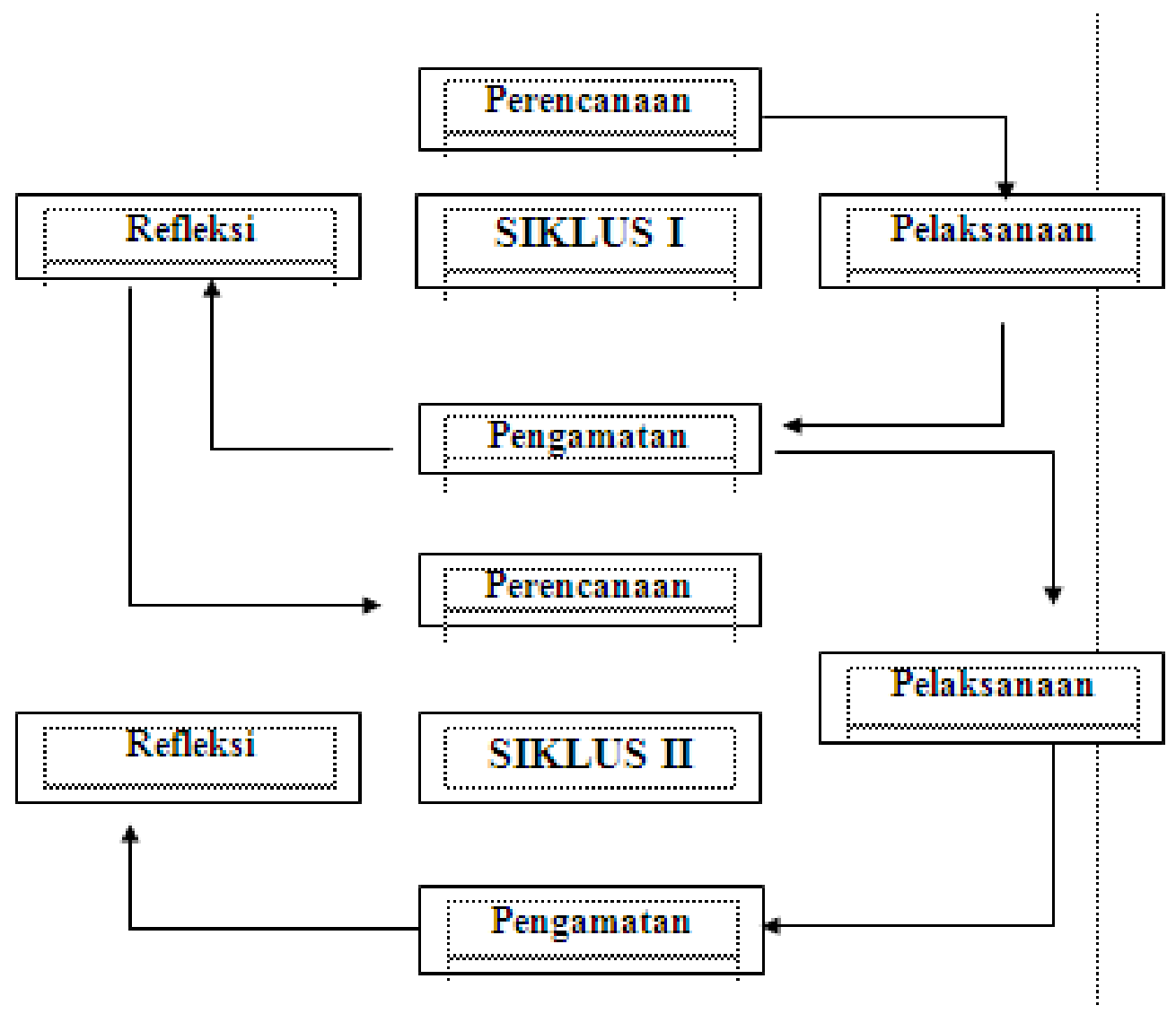


Menurut Suharsimi Arikunto (persentase 2005 : 10) metode pengumpulan data adalah kegiatan pengumpulan data agar kegiatan tersebut menjadi sistematis dan dipermudah. Olehnya metode pengumpulan data yang digunakan adalah metode observasi dandokumentasi, metode observasi yang digunakan yaituh berupa instrument untuk mencatat perkembanagan kemampuan siswa dalam kegiatan menggambar.

Untuk keefektifan kegiatan pembelajaran perlu diadakan analisa data, maka penganalisaan peneliti mengacu pada Anas Sudijono (2011:43)

Persentase $\mathrm{P}=\mathrm{n} / \mathrm{N} \times 100 \%$

Keterangan:

$\mathrm{P}=$ persentase yang hendak dicari

$\mathrm{n}=$ jumlah skor yang diperoleh

$\mathrm{N}=$ jumlah seluruh Skort ideal

\section{Meningkan Kreativitas Anak Usia Dini Melalui Aktivitas Menggambar}

Penelitian ini dilaksanakan di kelompok A pada Paud Tuan Guru Alim Kota Ternate dengan permasalahan kreativitas anak usia dini dengan aktivitas menggambar, denganjumlah siswa 10 anak diantaranya 6 perempuan dan 4 laki - laki, dalam kegiatan pembelajaran pada penelitian ini dilaksanakan dua siklus dan masing - masing siklus dirancang dua kali pertemuan, pada siklus pertama diaawali dengan pembelajaran kelompok maka terdapat tiga kelompok dan setiap kelompok terdiri 3 anggota kelompok dan satu kelompok terdiri 4 anggota, dan dua kelompoknya terdiri tiga anggota.

Pada hasil pembelajaran pada siklus I terdapat stau kelompok 1 memperoleh nilai 20\%, dalam kategori mulai berkembang (MB) sementara dua kelompok lainnya memaperoleh nilai 10\% dikategorikan belum berkembang (BB), sementara pada hasil eveluasi pembelajaran pembelajaran individu dilihat pada keluasan menggabar terdapat 2 anak 20\% memperoleh nilai 30 atau 37,5\% dikategorikan mulai berkembang (MB) dan dalam aspek keaslian dalam menggambar terdapat 3 anak atau 30\% memperoleh nilai 20 atau $25 \%$ dikategorikan sedang berkembang (SB), sementara apada aspek elaborasi terdapat 2 anak atau 20\% memperoleh nilai 15 atau 18,75\%, sementara 3 lainnya belum memiliki perkembangan.

Selanjutnya hasil evaluasi pembelajaran pada siklu II dilihat pada pembelajaran kelompok, mengalami peningkatan hal tersebut terlihat pada kelompo 1 dan kelompok 3 sudah mengalami peningkatan yakni pada siklus I memperoleh nilai $20 \%$ pada siklu II ini sudah menjadi $70 \%$, sementara pada hasil pembelajaran individu pada aspekkeluasan, keaslian dalam menggambar dan elaborasi terdapat 8 anak atau $80 \%$ memperoleh nilai 75 atau $93 \%$.

Pada proses pembelajaran kreativitas anak melalui kegiatan aktivita menggambar pada siklu satu masi terdapat anak - anak yang belum tuntas dalam pembelajaran kelompok maupun individu, hal ini disebabkan anak - anak belum terbiasa dalam hal menggabar, kemudian terjadi peningkatan pada siklus dua karena anak - anak sudah dibiasakan dan dilatih dalam pembelajaran khususnya pada kreativitas anak dengan kegiatan menggambar. 


\section{E. Simpulan}

Berdasarkan hasil analisis data maka beberapa kesimpulan yang diambil diantaranya:

1. Proses penilaian pada pembelajaran mellalui aktivitas menggambar terdapat $37,5 \%$ dikategorikan mulai berkembang (MB), dan 25\% dikategorikan sudah berkembang (SB), dan 18,75\% belum berkembang (BB).

2. Sementara pada siklus II mengalami peningkatan yang signifikan $70 \%$ sedang berkembang dan 93\% dikategorikan tuntas. Maka disimpulkan kreativitas anak melalui aktivitas menggambar pada kelompok A Paud Tuan Guru Alim Kota Ternate dapat meningkat secara optimal.

\section{DAFTAR PUSTAKA}

Ahmad Susanto, 2011. Perkembangan Anak Usia Dini Pengantar dalam Berbagai Aspeknya. Jakarta: Kencana Perdana Media Group.

Ali, M. Asrori, 2006. Psikologi Remaja Perkembangan Peserta Didik. PT Bumi Aksara: Jakarta.

Anas, Sudijono, 2002. Pengantar Statistic Pendidikan : Jakarta. Rineka Cipta.

Arikunto Suharsimi, 2005. Prosedur Penelitian: Jakarta. Rineka Cipta.

Depdiknas Dirjen Dikti 2005 pengembangan kreativitas senirupa anak TK. Jakarta

Hajar Pamadhi, 2008. Seni Ketrampilan Anak . Jakarta. Universitas Terbuka

Munandar, Utami 2009. Pengembangan Kreativitas Anak Berbakat. Jakarta: Rineka Cipta

Munandar, Utami 1995. Pengembangan kreativitas anak berbakat. Jakarta: rineka Cipta.

Suwarna, dkk 2005. Pengajaran Mikro Pendekatan Praktis Dalam Menyiapkan Pendidik Professional,. Yogyakarta: Tiara Wacana. 